\title{
Open University Library and Promote Community Education Resource Construction Development
}

\author{
Cheng Benqiang \\ (Shenzhen Open University , Shenzhen , 518001 , China)
}

Key words: Library; Community; Education resources

\begin{abstract}
Nowadays with economic, social and cultural development, education concept constantly updates, advancing with The Times development. People's lifestyle and custom change, and with material life quality improvement, more and more people tend to improve the quality of spiritual life. So in the new situation, university library amplifies its social function and its value has become a necessary choice. Nowadays colleges and society are exposed to increasing opportunities gradually. This article focuses on the opening of university library and the promotion of community education resource construction development.

One of the many functions of university library is the function of social education, which embodies and reflects the core competitiveness of university libraries. Now, the rapid development of economy and society provides a good opportunity for university library to actively play its social education function. Now under the development of the new era, people make higher requirement standard for university library to promote community education resource construction development, thus this has brought huge challenge to university library. Under such background, university library should break a new road toward community education development in order to satisfy the requirements of its development. This will make a new developing field for community development and will actively construct community cultural services, and actively promote community spirit and culture construction. Finally under the open condition of university library, community education resources construction development will be promoted.
\end{abstract}

\section{University library's social development}

\section{A. The social responsibility of university library}

Anything has both its own right and also its own duty, and university and university library are no exception. Therefore university library not only has its own social obligation, but has to fulfill its social obligations while carrying out its social responsibility. University library bears rich amount of information, and part of it is public cultural resources. University library always bears corresponding responsibilities, but can't always be active to improve the responsibility of its own. Its social public service function is simplified, and its own cognition is not clear in public social positioning, so it is especially important to let university library realize its responsibility correctly. Therefore, university library must actively set up responsibility consciousness, carefully confirm one by one social service projects earnestly, and make social reader s' problems get practical and effective solutions.

\section{B. University library's social position}

University library has not a good sense of responsibility, and is not accurate for its own position in society. So university library should make combined development of its own knowledge and society scientifically and reasonably. It is under the development of The Times that its stuck state in the past is effectively improved. Through contact with society, add dynamic factors in university library and provide community education resources with services. This is a way of its dynamism. Nowadays education concept shows updates and development trend. University library has gradually evolved into a platform for knowledge expansion strengthening and cultural transmission communication. So university libraries should clearly grasp social orientation. This will play a great role in promoting the positive development of university libraries, which is more conducive to its exchange and development with society and even embodies its social function. 


\section{The necessity of university library in community education resources}

\section{A. It is conducive to the realization of university library value}

Library is still. Only as a knowledge resources collection, it can't play its own value to the real effect. So only when it is used by people and society, its value can be played. Only when it is combined with social education resources development, it is given full play of its value. University library forms interaction relationship with society through its own opening, which not only benefits community, but will also enlarge scope of their own benefit, and can get the information feedback by the community, so it should make real-time inspection on the situation of books in the library, in time complete books, which can significantly improve its utilization and make greater play to its social value and better serve the community. At the same time, people's reasonable use of library resources in the community will help them to improve the overall quality and higher level of society so as to promote social harmony and progress, promote the construction of community culture, and let the society be on the road of sustainable development. So the open of university library to community people brings great convenience and intellectual, spiritual and cultural promotion, and at the same time, library itself also becomes meaningful and achieves its own value.

$B$. It is conducive to the realization of university library basic functions

The basic function of university library is for the development of community service, and Ministry of Education has issued relevant documents and clearly required that as much as possible university library should open to readers in society and community. The community service of university library is just the embodiment of its basic functions. Expand its services space and provide policy support for its services. So university library serves not only university teachers and students, but more opens to community and social clubs magnify its value indefinitely and sufficiently achieve its functions. Share actively cultural resources in the library and make its basic mission develop in the right direction.

\section{It is beneficial to the improvement of university library social responsibility}

The so-called community is a social activity group for people living in a specific area, and it is a small part of the society. It is also a small speaker of society. Although the range is not big, it contains many aspects of social activity. University library is a culture, a spirit, and even a carrier of civilization, which contains massive and abundant resources with great spiritual strength. So when university library opens to the society, it will give off its spirit power to great extent to enrich community people's spiritual world and improve their mental strength. University library should perfect its own responsibility and better serve community people. Reasonably use university library spare resources will enhance social people's cultural level and promote positive and healthy social development. So university library should firmly grasp the opportunity and social, friendly fuse with society and community, and serve community and society. Fully implement its own responsibility in serving and contributing to community.

\section{Open university library and promote the development of community education resources construction}

When university library serves community education, there should be strategies and plans for its own enthusiasm and education. Blind promotion is harmful rather than profitable, so corresponding countermeasure strategies may help university library be real implement for community education resources construction, and expand social education function of library and its advantage.

\section{A. Interact and share resource}

University library should not only be in the form of library in a pure sense, but should be the carrier of many kinds of information. Give strategic advice and settings on the opening and development of university library through corresponding countermeasure and plans in the community. University library has advanced means in modern society and can expand its own service to serve the community. With nowadays advanced network technology, share network resources and serve its advantages to the community, and enhance people's overall cultural level in the community. At the same time, community education quality carries on the qualitative leap 
through the quantity accumulation for a long time. Connect information intelligently, actively promote information service, and establish network sharing information resources platform. Make innovative study, enrich and expand community learning objects, learning content and learning space. Gradually increase the scope of its services ranging from small level to bigger. So the opening of university library should share resources by interaction between university library and community to actively promote the development of community education resources construction.

B. Improve service consciousness and ensure concept update

University library covers a lot of information which not just belongs to a university, but more belongs to social public resources, so university library has its own duty and its own responsibility so as to better serve the community and serving the society. University library, as college students and teachers information source, is an education form organization. It should actively play its own initiative, and can't always play its function passively and passively serve the society, so university library should break its close pattern and also break the concept. Really improve service consciousness to public service in concept. Open the propaganda door, and do a lot of propaganda work. Accompanied with a variety of public cultural services and form diversity, make community residents enjoy the sharing of resources at any time. By enhancing the service community consciousness of university library, ensure that it breaks traditional and original concept model, update theory development and actively promote the development of community education resources construction.

\section{Promote education function construction from community reality}

For the construction and development of university library's own culture and community service function promotion, according to the actual situation of university library and all aspects of actual community situation, standing on the actual starting point, take the readers of books in the library as the main center of its service, make its information service develop in advantage direction, as well as characteristic direction. Include a variety of information. To a certain level, strengthen friendly and close link with community residents committee, and let it reflect the truth of the people in the community. Meet people's demand on the basis of the community's real situation as far as possible. Add community education resources and on the basis of community education mode prosperity, and conveniently expand information education space. According to distinctive and advantageous resources, get together side by side with community, carry out smoothly community education, and let people in the community get cultivated by multiple levels of knowledge and culture. Fulfill people's entertainment demand and cultural appreciation in a community, and let more community people actively participate in university library. Let them enrich spiritual food and their knowledge and at the same time, make library have a youthful spirit and vitality. So from the reality of community, actively promote the development of community education resources construction.

\section{Conclusion}

University library itself is a platform with very rich amount of information and knowledge sharing. College students and college teachers enhance their knowledge quantity and enrich spiritual world with acknowledge of their own knowledge shortage. Today, with the rapid development of modern times, university library should actively conduct joint development, and make community people actively participate in learning knowledge. Improve the quality of community people, and university library should realize its basic functions and specify its own responsibility. Integrate and construct education resources in the community. Under the conditions of open university library, meet the pursuit of knowledge and education resources of community people, take advantage of its own characteristics, and promote common prosperity and development.

\section{References}

[1] Gao Shulian. Present situation and services research on university library open education resource construction [J]. Hebei Sci-Tech Library Journal, 2015 (1). 
[2] Yu Jiaqiang. Accelerate the development of community education with the construction of open university [J]. Journal of Guangdong Radio and TV University, 2011 (6).

[3] Liu Hong. Play social education function of university library in community education services [J]. Journal of Heilongjiang Institute of Education, 2015 (2).

[4] Meng Mohan. Toward community life: university library service function development [J]. Journal of CPC Shanxi Provincial Party Committee Party School, 2007 (6). 